\title{
The Preference of Women and Men Regarding Female Genital Depilation
}

\section{A preferência de mulheres e homens em relação à depilação genital feminina}

\author{
Maria Luiza Prudente de Oliveira Sangiorgi ${ }^{1}$ Lucia Alves da Silva Lara ${ }^{1}$ Maria Rita Lerri ${ }^{1}$ \\ Rui Alberto Ferriani ${ }^{2}$ Adriana Peterson Mariano Salata Romão ${ }^{1}$ \\ ${ }^{1}$ Clinic for Human Sexuality Research, Department of Gynecology \& \\ Obstetrics, Faculty of Medicine, Universidade de São Paulo, Ribeirão \\ Preto, SP, Brazil \\ 2 Human Reproduction Section, Department of Gynecology \& \\ Obstetrics, Faculty of Medicine, Universidade de São Paulo, Ribeirão \\ Preto, SP, Brazil \\ Address for correspondence Maria Luiza Prudente de Oliveira \\ Sangiorgi, MD, MSc, Departmento de Ginecologia \& Obstetrícia, \\ Hospital das Clínicas de Ribeirão Preto, Universidade de São Paulo, Av. \\ Bandeirantes, 3900, 80 andar, Ribeirão Preto, SP, 14049-900, Brazil \\ (e-mail: malusangiorgi@gmail.com).
}

Rev Bras Ginecol Obstet 2017;39:488-495.

\begin{abstract}
Purpose To evaluate the preferences of women and men regarding female pubic hair depilation and identify possible reasons for these preferences.

Methods This is a cross-sectional study of men and women over 18 years old who were invited by the official blog of our institution to respond anonymously to an online and self-administered questionnaire made by the researchers. The analyses were made using the Statistical Analysis System (SAS, SAS Inc., Cary, NC, US) software, version 9.3, and contingency tables were used to verify the distribution of variables. The univariate statistical analysis was performed using the Pearson chi-squared test, and the differences for values of $p<0.05$ were considered significant.

Results We obtained data from 69,920 subjects (52,787 women and 17,133 men). The mean age was 31.9 years for men, and 28.5 years for women. Most women (64.3\%) and men (62.2\%) preferred complete removal of female pubic hair, and this preference was more pronounced in younger women and men. Most women reported performing

Keywords

- depilation

- hair removal

- genitalia

- sexuality

- internet

- sexual behavior depilation at home (55.8\%), with $44.4 \%$ using hot wax and $40.1 \%$ using a razor blade. About half of the women (44.7\%) and men (50.1\%) reported sexual activity, having intercourse 2 to 3 times per week. The frequency of intercourse and sexual satisfaction in women correlated with total pubic hair removal.

Conclusion Most Brazilian women and men prefer the complete removal of female pubic hair, especially those who are younger and more sexually active. Women who are satisfied with the appearance of their own genitalia have a stronger preference for complete removal of pubic hair.
\end{abstract}

received

December 1, 2016

accepted

April 18, 2017

published online

August 7, 2017
DOI https://doi.org/

$10.1055 / \mathrm{s}-0037-1604472$.

ISSN 0100-7203.
Copyright @ 2017 by Thieme Revinter

Publicações Ltda, Rio de Janeiro, Brazil

License terms

(c) $(1) \$$ 


\section{Resumo}

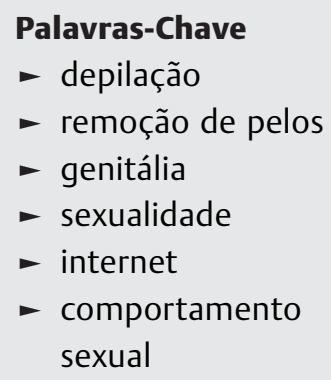

Objetivos Avaliar a preferência de mulheres e homens em relação à depilação genital feminina, e identificar possíveis razões envolvidas nessa preferência.

Método Estudo transversal em que homens e mulheres com mais de 18 anos foram convidados por meio do blog oficial de nossa instituição a responder anonimamente a um formulário on-line e autoadministrado de autoria dos pesquisadores. As análises foram realizadas no programa Statistical Analysis System (SAS, SAS Inc., Cary, Carolina do Norte, EUA), versão 9.3, e tabelas de contingência foram construídas para verificar a distribuição entre as variáveis. A análise estatística univariada foi realizada com o teste qui-quadrado de Pearson, e foram consideradas significativas as diferenças para $p<0,05$.

Resultados Foram obtidos dados de 69.920 indivíduos (52.787 mulheres e 17.133 homens). A idade média dos indivíduos foi de 31,9 anos entre os homens, e de 28,5 entre as mulheres. A maioria das mulheres $(64,3 \%)$ e dos homens $(62,2 \%)$ preferiram a genitália feminina completamente depilada, e essa preferência foi mais pronunciada em mulheres e homens mais jovens. A maioria das mulheres afirmaram se depilar em casa $(55,8 \%)$, e $44,4 \%$ delas usam cera quente, e $40,1 \%$ utilizam lâmina de barbear. Quase metade das mulheres $(44,7 \%)$ e metade dos homens $(50,1 \%)$ alegaram ter frequência sexual de 2 a 3 vezes por semana. A frequência sexual das mulheres e a satisfação com sua própria genitália foram positivamente relacionadas com a preferência pela remoção total dos pelos pubianos.

Conclusões A maioria das mulheres e dos homens brasileiros preferem a remoção completa dos pelos genitais femininos, o que é ainda mais pronunciado nos indivíduos mais jovens e sexualmente ativos. As mulheres satisfeitas com a aparência de sua própria genitália tendem a preferir a remoção completa dos pelos pubianos.

\section{Introduction}

Women have increasingly removed hair from their pubic regions since the second half of the twentieth century. ${ }^{1}$ There are many techniques used for this practice, including hot or cold wax, scissors or clippers, razors, depilatory creams, laser treatment, and electrolysis. ${ }^{2}$ Depilation in the pubic region may be related to sexual activity. Moreover, many additional factors may be related to pubic hair depilation, so this subject requires further investigation.

Giraldo et $\mathrm{al}^{3}$ studied 364 Brazilian college women, and reported that more than $90 \%$ practiced pubic hair removal; $57.6 \%$ reported partial removal, and $36.8 \%$ reported complete removal. In women from the United States, the extent of pubic hair removal appears to be associated with age and physical, social, and economic parameters. DeMaria and Berenson, ${ }^{4}$ in particular, collected data from 1,677 women, and reported that the habit of shaving was associated with being white, young (aged between 21-30 years), and at or below normal weight, and with having an annual household income greater than $\$ 30,000$ and 5 or more sexual partners over the lifetime. ${ }^{4}$ This study also reported the main reasons women removed their pubic hair were to achieve a cleaner appearance of the pubic region, and the belief that pubic hair is unattractive. ${ }^{4}$

Another study in the United States reported that women remove their pubic hair for hygienic reasons, comfort, and increased sensation during sex. ${ }^{5}$ Women may also remove their pubic hair to improve their sexual attractiveness. For example, in a study with 235 Australian women, Tiggermann and Hodgson ${ }^{6}$ observed that $60 \%$ of the subjects removed some pubic hair, and that $48 \%$ removed most or all of their pubic hair.

Butler et $\mathrm{al}^{7}$ evaluated the practices and preferences of pubic hair depilation in 1,110 men and women from two universities in the United States. They found that $95 \%$ of the subjects removed their pubic hair at least once every 4 weeks; women were more likely to report their status as completely depilated, and men were more likely to prefer sexual partners with completely depilated genitalia. ${ }^{7}$ In line with these results, a recent cross-sectional study in the United States examined 3,316 women, and found that most subjects (62\%) performed total pubic hair removal, and that older women were less likely to shave their pubic hair. ${ }^{8}$ Likewise, a study by Herbenick et $\mathrm{al}^{9}$ with 2,451 women from the United States observed that complete removal of pubic hair was associated with younger age.

An internet-based study aimed to characterize male preferences regarding vulvar appearance, and found that the subjects preferred the vulva partially (39\%) or completely (24\%) depilated, and that younger males were more likely to prefer complete hair removal. ${ }^{10}$ Schick et al $^{11}$ analyzed 647 photos from Playboy magazine published between 1953 and 2007, and 185 photos from this magazine published between 2007 and 2008. They found that the women had significantly less pubic hair over the years. ${ }^{11}$ Together, these observations 
indicate that the pornography industry has influenced female hair removal habits, because younger people who were exposed to this trend of hair removal for longer periods of their lives tend to show higher rates of complete pubic hair removal compared with older people.

Overall, these previous studies of preferences regarding female pubic hair removal indicate possible relationships with different sociodemographic parameters. However, more studies are needed to examine the factors related to female and male preferences regarding female pubic hair removal to evaluate the reproducibility of previously identified relationships, and to identify additional factors related to preferences. Additionally, most studies on female pubic hair depilation examined individuals from the United States. Studies in other countries can help to establish parallels between different cultures, and identify parameters that globally or locally influence the preference for female pubic hair depilation. Therefore, the aims of this study were to evaluate the preferences of Brazilian men and women regarding female pubic hair removal, and to identify the factors associated with different preferences.

\section{Methods}

This cross-sectional internet-based study recruited men and women from Brazil who were at least 18 years-old to fill out an online self-administered survey, without time limitation, entitled "Preference on Female Genital Depilation" from April 30, 2015 to August 31, 2015.The participants were invited via the official blog of the Clinic for Human Sexuality Research, from the Department of Gynecology \& Obstetrics of Ribeirão Preto Medical School. This study was broadly publicized in all regions of Brazil via radio interviews, television programs, and an online Brazilian newspaper. The survey form was developed by the researchers based on a previous pilot study (performed between September 18 , 2014 and October 18, 2014) that aimed to make the vocabulary of the questionnaire simple and accessible (data not shown). The variables were: sex, age, educational level, region of residence within Brazil, type of female pubic hair depilation preferred, motivation for this preference, sexual orientation, relationship status, weekly intercourse frequency, method and location from which pubic hair is removed, and satisfaction with the appearance of the genital region. This survey is part of a larger study, and contained 22 questions: 12 directed to both sexes, and 10 for women only. The necessary guidelines to understand and address the issues were in the statements of the survey and in each question, and there was no need for additional explanations. All participants were Brazilian men or women, who were at least 18 years old, and had internet access. The participants were excluded if they did not answer all the questions.

The survey used in this research project was approved by the Department of Gynecology \& Obstetrics Research Committee and the Ethics Committee of our institution (under protocol number $8497 / 2014$ ).

The answers of all subjects were viewed through a spreadsheet generated by Google Drive (Google, Inc., Moun- tain View, CA, US), and stored as Microsoft Excel (Microsoft Corporation, Redmond, WA, US) spreadsheets. The data in the spreadsheets were then imported into the Statistical Analysis System (SAS, SAS Inc., Cary, NC, US) software, version 9.3. Absolute and relative frequencies were estimated by the PROC FREQ procedure. Contingency tables were used to examine the variables of interest, and to determine frequency distributions. The univariate statistical analysis was performed using the Pearson chi-square test, and a $p<0.05$ was considered significant.

\section{Results}

We received responses from 86,187 individuals $(66,365$ women and 19,822 men). A total of 13,578 women and 104 men were excluded because they were younger than 18 years old and/or due to failure to answer 1 or more questions. Thus, we analyzed data from 69,920 subjects (52,787 women and 17,133 men) (-Table $\mathbf{1})$.

Most women were between 18 and 35 years old (82.14\%), and similar proportions were $18-25$ years old (42.22\%) and $26-35$ years-old (39.92\%). A smaller percentage of women were older than 36 years old $(17.86 \%)$. Most men were also between 18 and 35 years old (71.09\%), and $28.91 \%$ were older than 36 years old. However, a significantly greater portion of the men were $26-35$ years old (41.5\%) compared with those who were $18-25$ years old (17.91\%). Most men and women reported having incomplete undergraduate education, complete undergraduate education, or complete postgraduate education. Smaller numbers reported only having incomplete high school or complete high school degrees. Most participants were from the southeastern region of Brazil (women: 49.78\%, men: $54.81 \%)$.

Most women preferred to use hot wax (44.4\%) or a razor blade (40.1\%) to remove their pubic hair, and the remainder subjects reported the use of a variety of other methods (15.5\%). Most women performed depilation at home (55.8\%), and $30.5 \%$ had it performed in a beauty salon (-Table 1).

\section{Extent of Depilation and Reasons for Preferring Depilation}

Most women (64.3\%) and men (62.2\%) preferred complete depilation of the pubic region; $31.9 \%$ of women and $31.4 \%$ of men preferred partial depilation; and $2.6 \%$ of women and $4.3 \%$ of men preferred no depilation. Among women, the main reasons for pubic hair removal were hygiene ( $n=13,120 ; 24.8 \%$ ), a combination of beauty, hygiene, and sexual relations ( $n=12,890 ; 24.4 \%$ ), and hygiene and sexual relations $(n=7,800 ; 14.8 \%)$. Among men, the main reasons were beauty ( $n=3,728 ; 21.7 \%)$, and a combination of beauty, hygiene, and sexual relations ( $n=4,578 ; 26.7 \%)$. Thus, 37,205 (70.5\%) women considered hygiene one of the reasons for their depilatory practice, and $12,488(72.9 \%)$ men considered beauty as one of the reasons for their preference for pubic hair removal. 
Table 1 Characteristics of the study participants $(52,787$ women and 17,133 men)

\begin{tabular}{|c|c|c|}
\hline Variable & $\begin{array}{l}\text { Women } \\
\mathrm{n}(\%)\end{array}$ & $\begin{array}{l}\text { Men } \\
\text { n (\%) }\end{array}$ \\
\hline \multicolumn{3}{|l|}{ Age (in years): } \\
\hline $18-25$ & $22,288(42.22)$ & $5,069(29.59)$ \\
\hline $26-35$ & $21,070(39.92)$ & $7,111(41.50)$ \\
\hline $36-45$ & $7,458(14.13)$ & $3,068(17.91)$ \\
\hline$>45$ & $1,971(3.73)$ & $1,885(11)$ \\
\hline \multicolumn{3}{|l|}{ Level of education: } \\
\hline Postgraduate & $11,569(21.92)$ & $4,194(24.48)$ \\
\hline $\begin{array}{l}\text { Undergraduate } \\
\text { (complete) }\end{array}$ & $13,763(26.07)$ & $5,399(31.51)$ \\
\hline $\begin{array}{l}\text { Undergraduate } \\
\text { (incomplete) }\end{array}$ & $15,976(30.27)$ & $4,659(27.19)$ \\
\hline $\begin{array}{l}\text { High school } \\
\text { (complete) }\end{array}$ & $9,540(18.07)$ & $2,416(14.10)$ \\
\hline $\begin{array}{l}\text { High school } \\
\text { (incomplete) }\end{array}$ & $1,565(2.96)$ & $380(2.22)$ \\
\hline Other & $374(0.71)$ & $85(0.50)$ \\
\hline \multicolumn{3}{|c|}{ What region of Brazil are you from? } \\
\hline Midwest & $5,098(9.66)$ & $1,725(10.07)$ \\
\hline Northeast & 9,551 (18.09) & $3,037(17.73)$ \\
\hline North & $2,393(4.53)$ & $504(2.94)$ \\
\hline Southeast & $26,277(49.78)$ & $9,390(54.81)$ \\
\hline South & $9,468(17.94)$ & $2,477(14.46)$ \\
\hline \multicolumn{3}{|c|}{ What kind of female genital depilation do you prefer? } \\
\hline Complete & $33,927(64.27)$ & $10,655(62.19)$ \\
\hline Partial & $16,835(31.89)$ & $5,376(31.38)$ \\
\hline None & $14,01(2.65)$ & $730(4.26)$ \\
\hline Other & $624(1.18)$ & $372(2.17)$ \\
\hline \multicolumn{3}{|c|}{ What is the reason for your preference? } \\
\hline Beauty & $4,451(8.43)$ & $3,728(21.76)$ \\
\hline Hygiene & $13,120(24.85)$ & $711(4.15)$ \\
\hline Sexual relations & $5,353(10.14)$ & $2,663(15.54)$ \\
\hline Beauty and hygiene & $3,395(6.43)$ & $1,106(6.46)$ \\
\hline $\begin{array}{l}\text { Beauty, hygiene } \\
\text { and sexual } \\
\text { relations }\end{array}$ & $12,890(24.42)$ & $4,578(26.72)$ \\
\hline $\begin{array}{l}\text { Beauty and sexual } \\
\text { relations }\end{array}$ & $2,131(4.04)$ & $3,076(17.95)$ \\
\hline $\begin{array}{l}\text { Hygiene and sexual } \\
\text { relations }\end{array}$ & $7,800(14.78)$ & $572(3.34)$ \\
\hline Other & $3,647(6.91)$ & $699(4.08)$ \\
\hline \multicolumn{3}{|l|}{ Sexual orientation: } \\
\hline Heterosexual & $49,313(93.42)$ & $16,707(97.51)$ \\
\hline Homosexual & $11,45(2.17)$ & $175(1.02)$ \\
\hline Bisexual & $2,248(4.26)$ & 238 (1.39) \\
\hline Other & $81(0.15)$ & $13(0.08)$ \\
\hline
\end{tabular}

(Continued)
Table 1 (Continued)

\begin{tabular}{|c|c|c|}
\hline Variable & $\begin{array}{l}\text { Women } \\
\text { n (\%) }\end{array}$ & $\begin{array}{l}\text { Men } \\
\text { n (\%) }\end{array}$ \\
\hline \multicolumn{3}{|l|}{ Relationship status: } \\
\hline None & $11,579(21.94)$ & $2,530(14.77)$ \\
\hline Dating exclusively & $20,198(38.26)$ & $6,536(38.15)$ \\
\hline Married & $21,010(39.80)$ & $8,067(47.08)$ \\
\hline \multicolumn{3}{|c|}{ How often do you have sex? } \\
\hline No sexual activity & $4,813(9.12)$ & $557(3.25)$ \\
\hline Up to once per month & $214(0.41)$ & $51(0.30)$ \\
\hline Up to once per week & $13,076(24.77)$ & $3,482(20.32)$ \\
\hline $\begin{array}{l}\text { Two to three times } \\
\text { per week }\end{array}$ & $23,589(44.69)$ & $8,593(50.15)$ \\
\hline $\begin{array}{l}\text { More than three } \\
\text { times per week }\end{array}$ & $11,095(21.02)$ & $4,450(25.97)$ \\
\hline \multicolumn{3}{|c|}{ You prefer to depilate with: } \\
\hline Hot wax & $23,427(44.38)$ & $*$ \\
\hline Cold wax & $671(1.27)$ & * \\
\hline Razor blade & $21,168(40.10)$ & $*$ \\
\hline Depilatory cream & $1,557(2.95)$ & $*$ \\
\hline Laser & $3,029(5.74)$ & $*$ \\
\hline Electric razor & $1,807(3.42)$ & $*$ \\
\hline Other & $1,128(2.14)$ & $*$ \\
\hline \multicolumn{3}{|l|}{ Where do you depilate? } \\
\hline Home & $29,456(55.80)$ & * \\
\hline Beauty Salon & $16,115(30.53)$ & $*$ \\
\hline Clinic & $6,677(12.65)$ & * \\
\hline Other & $539(1.02)$ & * \\
\hline \multicolumn{3}{|c|}{ Are you satisfied with the appearance of your genital area } \\
\hline Dissatisfied & $1,683(3.19)$ & $*$ \\
\hline Slightly satisfied & $9,260(17.54)$ & $*$ \\
\hline Satisfied & 29,654 (56.18) & * \\
\hline Very satisfied & $12,190(23.09)$ & $*$ \\
\hline
\end{tabular}

Note: * Questions that were exclusive to women.

\section{Preferences in Different Age Groups}

Our analysis of different age groups indicated that complete removal of pubic hair was preferred by most women who were between 18 and 25 years old (74.26\%) and 26 to 35 years old (60.47\%), and this preference gradually declined with age (-Table 2). In contrast, the women's preference for partial depilation increased with age, and this preference was reported by $48.96 \%$ of women who were older than 45 years old. Among men, the preference for complete depilation also decreased with age, and the preference for partial depilation increased with age. Among all age groups, only a small number of men and women preferred no depilation, although this preference also increased with age. 
492 Preference of Women and Men Regarding Female Genital Depilation Sangiorgi et al.

Table 2 Preferences for extent of female pubic hair removal in different age groups of women and men

\begin{tabular}{|c|c|c|c|c|c|c|c|}
\hline & \multirow[b]{2}{*}{ Age group, years } & \multicolumn{5}{|c|}{ Preferred extent of female pubic hair removal } & \multirow[b]{2}{*}{$p$} \\
\hline & & Complete & Partial & None & Other & Total & \\
\hline \multirow{4}{*}{$\begin{array}{l}\text { Women } \\
\mathrm{n}(\%)\end{array}$} & $18-25$ & $16,551(74.26)$ & $4,900(21.98)$ & $617(2.77)$ & $220(0.99)$ & $22,288(100)$ & \multirow[t]{4}{*}{$<0.0001$} \\
\hline & $26-35$ & $12,741(60.47)$ & $7,609(36.11)$ & $476(2.26)$ & $244(1.16)$ & $21,070(100)$ & \\
\hline & $36-45$ & $3,766(50.5)$ & $3,361(45.07)$ & $215(2.88)$ & $116(1.56)$ & $7,458(100)$ & \\
\hline & $>45$ & 869 (44.09) & $965(48.96)$ & $93(4.72)$ & $44(2.23)$ & $1,971(100)$ & \\
\hline \multirow{4}{*}{$\begin{array}{l}\text { Men } \\
n(\%)\end{array}$} & $18-25$ & $3,499(69.03)$ & $1,320(26.04)$ & $146(2.88)$ & $104(2.05)$ & $5,069(100)$ & \multirow[t]{4}{*}{$<0.0001$} \\
\hline & $26-35$ & $4,485(63.07)$ & $2,253(31.68)$ & $240(3.38)$ & $133(1.87)$ & $7,111(100)$ & \\
\hline & $3-45$ & $1,689(55.05)$ & $1,146(37.35)$ & $161(5.25)$ & $72(2.35)$ & $3,068(100)$ & \\
\hline & $>45$ & $982(52.10)$ & $657(34.85)$ & $183(9.71)$ & $63(3.34)$ & $1,885(100)$ & \\
\hline
\end{tabular}

\section{Preferences for Pubic Hair Removal and Sexual Orientation}

Most of the men (97.5\%) and women (93.4\%) were heterosexual (-Table 1). The majority of women who were heterosexual (64.5\%), homosexual (62.4\%), and bisexual (60.2\%) all preferred complete removal of pubic hair (-Table 3). Similarly, most men who were heterosexual (62.27\%), homosexual (61.71\%), and bisexual (57.56\%) also preferred complete removal of pubic hair.

\section{Preferences on the Extent of Pubic Hair Removal and Frequency of Intercourse}

We found that most women (44.7\%) and men (50.1\%) reported having intercourse 2 to 3 times per week, and smaller percentages ( $\sim 22 \%$ ) of women and men reported a frequency of up to once per week or more than 3 times per week. Significantly fewer men and women reported having no intercourse or a frequency of once per month ( - Table $\mathbf{1}$ ).

Regardless of the frequency of intercourse, total removal of pubic hair was preferred by most women and men (-Table 4). The percentage of women and men who preferred total removal of pubic hair increased with the frequency of intercourse, and was greatest for women (72.2\%) and men (65.8\%) who reported having intercourse more than
3 times per week. Similar percentages of men and women who preferred partial pubic hair removal reported no intercourse up to intercourse 2-3 times per week, and the lowest percentage of preference for partial depilation was among women and men who declared a sexual frequency of more than 3 times per week. Very few women and men preferred no pubic hair removal in all intercourse frequency groups, but there was a trend for a decline in this preference with an increase in the frequency of intercourse.

\section{Preferences for the Extent of Pubic Hair Removal and Satisfaction with Genital Appearance}

A total of $56.2 \%$ of women reported being satisfied, and $23.1 \%$ were very satisfied with the appearance of their genitalia (-Table 1). A total of $20.7 \%$ of women reported being dissatisfied or only slightly satisfied with the appearance of their genitalia.

Most women preferred complete removal of their pubic hair, irrespective of the extent of their satisfaction with the appearance of their genitalia (-Table 5). The highest and lowest percentages of women who preferred complete depilation were those who reported being very satisfied (68.6\%) and dissatisfied (60.6\%) respectively. The percentage of women who reported a preference for partial hair removal

Table 3 Preferences regarding the extent of female pubic hair removal in men and women with different sexual orientations

\begin{tabular}{|c|c|c|c|c|c|c|c|}
\hline & & \multicolumn{5}{|c|}{ Preferred extent of female pubic hair removal } & \multirow[b]{2}{*}{$p$} \\
\hline & Sexual orientation & Complete & Partial & None & Other & Total & \\
\hline \multirow{4}{*}{$\begin{array}{l}\text { Women } \\
\mathrm{n}(\%)\end{array}$} & Heterosexual & $31,823(64.53)$ & $15,849(32.14)$ & $1,116(2.26)$ & $525(1.06)$ & $49,313(100)$ & \multirow[t]{4}{*}{$<0.0001$} \\
\hline & Homosexual & $714(62.36)$ & $351(30.66)$ & $61(5.33)$ & $19(1.66)$ & $1,145(100)$ & \\
\hline & Bisexual & $1,354(60.23)$ & $620(27.58)$ & $203(9.03)$ & $71(3.16)$ & $2,248(100)$ & \\
\hline & Other & $36(44.44)$ & $15(18.52)$ & $21(25.93)$ & $9(11.11)$ & $81(100)$ & \\
\hline \multirow{4}{*}{$\begin{array}{l}\text { Men } \\
n(\%)\end{array}$} & Heterosexual & $10,404(62.27)$ & $5,250(31.42)$ & $698(4.18)$ & $355(2.12)$ & $16,707(100)$ & \multirow[t]{4}{*}{$<0.0001$} \\
\hline & Homosexual & $108(61.71)$ & $52(29.71)$ & $6(3.43)$ & $9(5.14)$ & $175(100)$ & \\
\hline & Bisexual & $137(57.56)$ & $73(30.67)$ & $24(10.08)$ & $4(1.68)$ & $238(100)$ & \\
\hline & Other & $6(46.15)$ & 1 (7.69) & $2(15.38)$ & $4(30.77)$ & $13(100)$ & \\
\hline
\end{tabular}


Table 4 Preferences for the extent of female pubic hair removal and frequency of sexual intercourse in women and men

\begin{tabular}{|c|c|c|c|c|c|c|c|}
\hline & & \multicolumn{5}{|c|}{ Preferred extent of female pubic hair removal } & \multirow[b]{2}{*}{$p$} \\
\hline & Sexual frequency & Complete & Partial & None & Other & Total & \\
\hline \multirow{5}{*}{$\begin{array}{l}\text { Women } \\
\mathrm{n}(\%)\end{array}$} & No sexual activity & $2,774(57.64)$ & $1,716(35.65)$ & $248(5.15)$ & $75(1.56)$ & $4,813(100)$ & \multirow[t]{5}{*}{$<0.0001$} \\
\hline & Up to once per month & $120(56.07)$ & $74(34.58)$ & $10(4.67)$ & $10(4.67)$ & $214(100)$ & \\
\hline & Up to once per week & $7,842(59.97)$ & $4,717(36.07)$ & $368(2.81)$ & $149(1.14)$ & $13,076(100)$ & \\
\hline & 02 to 03 times per week & $15,184(64.37)$ & $7,590(32.18)$ & $546(2.31)$ & $269(1.14)$ & $23,589(100)$ & \\
\hline & $>03$ times per week & $8,007(72.17)$ & $2,738(24.68)$ & $229(2.06)$ & $121(1.09)$ & $11,095(100)$ & \\
\hline \multirow{5}{*}{$\begin{array}{l}\text { Men } \\
\mathrm{n}(\%)\end{array}$} & No sexual activity & $314(56.37)$ & $186(33.39)$ & $35(6.28)$ & $22(3.95)$ & $557(100)$ & \multirow[t]{5}{*}{$<0.0001$} \\
\hline & Up to once per month & $27(52.94)$ & $18(35.29)$ & $4(7.84)$ & $2(3.92)$ & $51(100)$ & \\
\hline & Up to once per week & $2,071(59.48)$ & $1,188(34.12)$ & $155(4.45)$ & $68(1.95)$ & $3,482(100)$ & \\
\hline & 02 to 03 times per week & $5,315(61.85)$ & $2,748(31.98)$ & $362(4.21)$ & $168(1.96)$ & $8,593(100)$ & \\
\hline & $>03$ times per week & $2,928(65.8)$ & $1,236(27.78)$ & $174(3.91)$ & $112(2.52)$ & $4,450(100)$ & \\
\hline
\end{tabular}

was similar in the 4 groups who reported different levels of satisfaction with their genital appearance $(\sim 32 \%)$. A significant minority of women in all four groups preferred no depilation.

\section{Discussion}

This study evaluated the preferences of Brazilian women and men regarding female pubic hair removal by women, and the relationships of different preferences with sociodemographic parameters and factors related to sexual activity. Our self-administered and online survey has data from 69,920 subjects, the largest sample size so far reported among studies on female pubic hair depilation.

Our analysis indicated that $64.3 \%$ of women and $62.2 \%$ of men preferred female genitalia with no hair at all. Moreover, the complete removal of female pubic hair was preferred by women and men in all regions of Brazil. These findings are in line with the results of multiple studies conducted in the US. ${ }^{7,8,11}$ However, our findings differ from those of Giraldo et $\mathrm{al}^{3}$ in Brazil, Herbenick et $\mathrm{al}^{9}$ in the USA, and Tiggermann and Hodgson ${ }^{6}$ in Australia, who reported that women preferred partial removal of pubic hair, and from those of Mazloomdoost et al, ${ }^{10}$ who reported that men from the US preferred partial depilation. These differences may be due to cultural differences. Furthermore, comparisons of studies of the same population indicated that the preference for complete pubic hair removal has increased over time.

We observed that women and men of similar age, educational level, relationship status, and frequency of intercourse had similar preferences regarding the removal of pubic hair in general, and regarding the extent of pubic hair removal. This indicates a positive feedback between women and men regarding their preferences for female pubic hair depilation. Moreover, there is a possibility that the preferences of men and women with similar characteristics are influenced by the same external (unmeasured) factors that determine their preferences regarding female pubic hair removal.

The present study indicated that younger men and women were more likely to prefer complete pubic hair removal in women, but older men and women were more likely to prefer partial depilation. These observations are in accordance with other studies ${ }^{4,7-10,12}$ and with the recent trend for complete removal of female pubic hair reported by Schick et al. ${ }^{11}$

Our analysis of the reason for preferring female pubic hair depilation indicated that hygiene was the major reason in women, and beauty was the major reason in men. Even though the presence of body hair in general is not associated with poor hygiene, many people apparently believe that pubic hair can accumulate debris and complicate genital cleaning, and thereby facilitate the acquisition of infections.

Table 5 Preferences for the extent of female pubic hair removal in women who reported different levels of satisfaction with the appearance of their genitalia

\begin{tabular}{|c|c|c|c|c|c|c|c|}
\hline & & \multicolumn{5}{|c|}{ Preferred extent of female pubic hair removal } & \multirow[b]{2}{*}{$p$} \\
\hline & $\begin{array}{l}\text { Satisfaction with genital } \\
\text { appearance }\end{array}$ & Complete & Partial & None & Other & Total & \\
\hline \multirow{4}{*}{$\begin{array}{l}\text { Women } \\
\mathrm{n}(\%)\end{array}$} & Dissatisfied & $1,020(60.61)$ & $555(32.98)$ & $92(5.47)$ & $16(0.95)$ & $1,683(100)$ & \multirow[t]{4}{*}{$<0.0001$} \\
\hline & Slightly satisfied & $5,761(62.21)$ & $3,178(34.32)$ & $231(2.49)$ & $90(0.97)$ & $9,260(100)$ & \\
\hline & Satisfied & $18,778(63.32)$ & $9,914(33.43)$ & $650(2.19)$ & $312(1.05)$ & $29,654(100)$ & \\
\hline & Very satisfied & $8,368(68.65)$ & $3,188(26.15)$ & $428(3.51)$ & $206(1.69)$ & $12,190(100)$ & \\
\hline
\end{tabular}


This may explain why women considered hygiene as the major reason for removal of pubic hair. Other studies also reported associations between female pubic hair depilation and hygiene. ${ }^{4,5,7,8}$

The results of this study are consistent with previous studies that reported that consuming pornography and erotica can influence preferences for pubic hair removal, as reported by Desruelles et $\mathrm{al}^{13}$ and Ramsey et al. ${ }^{14}$ However, this influence must be further investigated in order to evaluate this relationship more directly. Besides, more studies are needed to analyze the influence of the media in general and of the internet and social media on the increasing preference for pubic hair depilation.

We also evaluated preferences for different types of female pubic hair removal in women and men with different sexual orientations. Interestingly, most women and men who defined themselves as heterosexual, homosexual, and bisexual preferred complete removal of female pubic hair. These observations suggest that the same factor(s) may influence the preferences of subjects with different sexual orientations.

Our study also indicates that women and men who have intercourse with greater frequency were more likely to prefer complete removal of female pubic hair. This may be related to our observation that men view hairless genitalia as more attractive, and women view hairless genitalia as more hygienic. Other studies also reported associations of the preference for complete depilation and greater sexual activity. ${ }^{9,12,15}$ In line with these observations, we also found that, in general, subjects who preferred no depilation had lower frequencies of intercourse.

The results of the present study indicate that women who are less satisfied with the appearance of their own genitalia were less likely to perform complete pubic hair removal, and had a greater preference for no removal of pubic hair. Likewise, women who reported being satisfied with the appearance of their own genitalia were more likely to prefer complete depilation. Thus, a woman who is dissatisfied with the appearance of her own genitalia may not remove her pubic hair, simply because it conceals her genitalia.

All relationships examined in this work had $p$-values much lower than the proposed level of significance $(p<0.05)$. A major strength of this study is that it is the largest study of Brazilian people to evaluate the preferences of women and men regarding the removal of female pubic hair. Our study identified several sociodemographic and other factors related to the preference for hair removal. As a whole, our findings provide an important basis to understand the motivations for the now widespread practice of female pubic hair depilation.

\section{Limitations}

A limitation of this study is that we recruited participants via the internet, and there were therefore biases inherent to the use of convenience sampling. All participants filled out the forms anonymously and privately, and we have no evidence regarding their understanding of the questions or the accuracy of their answers. However, due to the large number of participants, we expect that any intentionally or unintentionally inaccurate answers would be overwhelmed by the larger number of accurate answers. In addition, we used a pilot study to assure the adequacy of the language used in the survey. All participants were literate and had access to the internet, so we excluded those who were illiterate and had no internet access. Internet access in Brazil does not cover urban and rural areas equally, and is not available to many individuals from lower socioeconomic strata, so this may have biased our results. However, we believe these limitations, which are inherent to the use of the internet to recruit subjects, are overwhelmed by the several advantages provided by using the internet, such as the ability to recruit a very large sample, the absence of biases introduced by the physical presence of researchers during the interview, and the minimal expenses needed to conduct large surveys. The possibility of a non-representative sample, a limitation inherent to convenience sampling, may have been overcome by our extensive publicity of the survey, so that Brazilians from all regions, of all ages, and with all educational levels, were aware of the study.

\section{Conclusions}

This study found that Brazilian women and men prefer female genitalia without any hair, and that this preference was stronger for younger people. This preference may be due to the influence of recent trends in beauty, aesthetics, eroticism, and pornography. Women reported the main motivation for the removal of female pubic hair is hygiene, and men reported the main reason for this preference is beauty. Men and women who have more frequent intercourse are more likely to prefer complete depilation, and women who are more satisfied with the appearance of their own genitalia are more likely to prefer complete depilation.

\section{Acknowledgments}

This work was funded by the Brazilian National Council for Scientific and Technological Development (CNPq, in the Portuguese acronym, under process 130144/2015-0). We thank Bruno Sangiorgi for his great contribution in all steps of this study, and Suleimy Mazin for her work on the analysis.

Contributions: 1. Substantial contributions to conception and design, data collection or analysis, and interpretation of data: Maria Luiza Prudente de Oliveira Sangiorgi, Lucia Alves da Silva Lara, Maria Rita Lerri, Rui Alberto Ferriani, Adriana Peterson Mariano Salata Romão.

2. Writing of the article or critical review of the intellectual content: Maria Luiza Prudente de Oliveira Sangiorgi, Lucia Alves da Silva Lara, Adriana Peterson Mariano Salata Romão.

3. Final approval of the version to be published: Maria Luiza Prudente de Oliveira Sangiorgi, Lucia Alves da Silva 
Lara, Maria Rita Lerri, Rui Alberto Ferriani, Adriana Peterson Mariano Salata Romão.

\section{Conflicts of Interest}

The authors have no conflicts of interest to declare.

\section{References}

1 Glass AS, Bagga HS, Tasian GE, et al. Pubic hair grooming injuries presenting to U.S. emergency departments. Urology 2012;80(06): 1187-1191

2 Dendle C, Mulvey S, Pyrlis F, Grayson ML, Johnson PD. Severe complications of a "Brazilian" bikini wax. Clin Infect Dis 2007;45 (03):e29-e31

3 Giraldo PC, Polo RC, do Amaral RL, Reis VV, Beghini J, Bardin MG. [Habits and traditions of female college students related to intimate clothing, genital adornments, genital hair removal and sexual practices]. Rev Bras Ginecol Obstet 2013;35(09):401-406 Portuguese

4 DeMaria AL, Berenson AB. Prevalence and correlates of pubic hair grooming among low-income Hispanic, Black, and White women. Body Image 2013;10(02):226-231

5 DeMaria AL, Sundstrom B, McInnis SM, Rogers E. Perceptions and correlates of pubic hair removal and grooming among collegeaged women: a mixed methods approach. Sex Health 2016;13 (03):248-256

6 Tiggermann M, Hodgson S. The hairlessness norm extended: reasons for and predictors of women's body hair removal at different body sites. Sex Roles 2008;59(11):889-897
7 Butler SM, Smith NK, Collazo E, Caltabiano L, Herbenick D. Pubic hair preferences, reasons for removal, and associated genital symptoms: comparisons between men and women. J Sex Med 2015;12(01):48-58

8 Rowen TS, Gaither TW, Awad MA, Osterberg EC, Shindel AW, Breyer BN. Pubic hair grooming prevalence and motivation among women in the United States. JAMA Dermatol 2016;152 (10):1106-1113

9 Herbenick D, Schick V, Reece M, Sanders S, Fortenberry JD. Pubic hair removal among women in the United States: prevalence, methods, and characteristics. J Sex Med 2010;7(10):3322-3330

10 Mazloomdoost D, Crisp CC, Westermann LB, Benbouajili JM, Kleeman SD, Pauls RN. Survey of male perceptions regarding the vulva. Am J Obstet Gynecol 2015;213(05):731.e1-731.e9

11 Schick VR, Rima BN, Calabrese SK. Evulvalution: the portrayal of women's external genitalia and physique across time and the current barbie doll ideals. J Sex Res 2011;48(01):74-81

12 Herbenick D, Hensel D, Smith NK, et al. Pubic hair removal and sexual behavior: findings from a prospective daily diary study of sexually active women in the United States. J Sex Med 2013;10 (03):678-685

13 Desruelles F, Cunningham SA, Dubois D. Pubic hair removal: a risk factor for 'minor' STI such as molluscum contagiosum? Sex Transm Infect 2013;89(03):216

14 Ramsey S, Sweeney C, Fraser M, Oades G. Pubic hair and sexuality: a review. J Sex Med 2009;6(08):2102-2110

15 Bercaw-Pratt JL, Santos XM, Sanchez J, Ayensu-Coker L, Nebgen DR, Dietrich JE. The incidence, attitudes and practices of the removal of pubic hair as a body modification. J Pediatr Adolesc Gynecol 2012;25(01):12-14 